\title{
Emerging Developments in Call Centre Research
}

\section{John Burgess and Julia Connell}

\begin{abstract}
Over the past ten years there has been a massive growth in call centres worldwide. Developments in the industry have attracted many researchers, especially in the area of labour process where call centres bring with them continuous production, standardised work and potential for forms of extreme control and monitoring of work. However, the global nature of the industry means that jobs will always be susceptible to outsourced operations. Information and communication technology [ITC] developments, public sector subsidisation of business restructuring and relocation, and the possibility of cheaper operations being offered elsewhere will mean that the industry will undergo ongoing transformation. In call centre development, the information age comes up against the factory age in terms of job design and management strategies, and the local economy comes up against the global econony in terms of the footloose nature of the industry. This paper represents an overview of the research issues associated with call centre development in Ausiralia and elsewhere.
\end{abstract}

\section{Introduction}

Call centres vary widely in terms of size, industry, labour market, services performed, technologies used, and the management practices they implement. If anything it is the heterogeneous, not homogeneous, nature of call centres that is striking (Deery \& Kinnie 2002). It is easy to think of a typical call centre as a large warehouse-type arrangement with 200-300 employees. This may be the case for established call centres in industries such as banking and finance, telecommunications or utilities, but is unlikely to be the case for more recent entrants to the market, where call centre size is typically around 30-50 employees and technology is more sophisticated. Indeed, in some countries, such as New Zealand (see Hunt in this volume), the typical call centre has fewer than 50 employees. Predictions for continued growth in the call centre market see much of the expansion coming from smaller operations. This is partly because the advent of new technologies, combined with falling prices, has made call centre technology more affordable for smaller players (Anonymous 2002). 
Over the past decade in Australia, call centres have evolved and expanded in response to information and communication technology [ICT] developments, business outsourcing practices, and the internal reorganisation of enterprises (Burgess, Connell \& Drinkwater 2002). While the business service sector including banks, insurance, airlines, utilities, and travel companies are all major participants in call centre operations, the spread and reach of call centres is across all industries from community and public services through to manufacturing industry customer enquiries. One prominent feature of the evolution and development of call centre operations is that the functions performed in call centres are potentially relevant for all industries and all enterprises across all sectors, including public and private, market and non-market activities.

The development and growth in the number of call centre operations has for the most part evolved from internal business re-organisation. It is evident that one of the major drivers behind the proliferation of call centres has been the pursuit of flexibility. This has been substantiated by the number of call centre functions that are now outsourced. Call centres illustrate flexibility in all of its forms: numerical - part-time and temporary staff (Incomes Data Services [IDS] 2001); functional - fluctuating levels of customer interaction; and temporal - the end of the 9-5 workforce (Taylor et al. 2002). In banking, retail branches have been closed and face-to-face services have diminished. Banks use call centres to deal with customer enquiries but also to market new products. In this sense, call centres constitute a form of vertical disintegration of a business organisation and allow for the restructuring of internal labour markets. Certain functions are packaged, separated and re-located away from high rental retail branches and head offices. Call centres are, in this context, part of the internal restructuring of business operations, the segmentation of service delivery and the extended division of labour within an organisation. This restructuring process is clearly facilitated by IT developments that allow for the intensive division of labour and the external re-location of call centre functions. In turn, full-time career jobs attached to an enterprise can be removed and replaced with outsourced jobs in outsourced businesses. Often these jobs can be part-time or casual, or in many cases they may involve contract work, typically through agencies (Australian Council of Trade Unions [ACTU] 2003a). The process has also been facilitated through a range of government assistance packages to subsidise call centre start up and on going operations, especially in regional locations (Burgess, Connell \& Drinkwater 2002; Dean \& Rainnie 2002).

Call centres are not of ficially classified as an industry but are regarded as a derivative component of the businesses whose services they deliver. Call centres are not industry, product or service specific. Any type of service can be delivered through a call centre. In fact 'contact centre' has replaced the term call centre in the industry terminology, reflecting the fact that operations in addition to telephony are now being conducted. The range of actual and potential services that can be locited in a call centre is increasing as communications technology is upgraded and new software is developed and applied. In part, this reflected the development of call centres as largely within house operations to 
handle customer enquiries and to market business products. However, call centres have moved towards independent operations, often sub-contracting specialist services to a host of clients, in many cases these specialists have operations across many cominents (Burgess, Connell \& Drinkwater 2002). No longer is the call centre exclusively part of a larger organisation nor is it the exclusive domain of large businesses. This dynamic contributes to its transient nature and in turn it is supported by and manifested through its global reach.

\section{Call Centre Research: the Dominant Issues}

The literature on call centres is vast and growing, reflecting the development of the industry. However, there are a number of dominant research areas to date. The first is the concentration of research on the labour process of call centre work within a Taylorist paradigm. Call centres are represented as the service sector equivalent to industrial manufacturing with large scale and continuous production, extensive monitoring and control of the workforce, and the routinisation and repetition of work tasks. Work organisation, control, and subordination are key characteristics of work that is boring, repetitive, and tiring (Taylor \& Bain 1999; Taylor et al. 2002; Rose 2002). There can be extensive scripting and monitoring, time limits on calls, and required quotas of calls per hour. Call centre workers are the new face of the industrial proletariat and the emergence of the call centre represents a continuity of large scale industrial production processes (Russell 2002; van den Broek 2002). While the forms of control and regulation may be more subtle and technologically advanced (Rose 2002), the underlying process and motivation for its application remains the same. The irony is that in a post industrial age, and with an industry so closely tied to ICT developments, the same characteristics of work and work organisation that were present in the industrial factory are present in the contemporary call centre. A detailed overview of the labour process analysis of call centres can be found in the contribution by Russell in this volume.

The second area of research is associated with forms of resistance and coping by workers. Resistance may be explicit and expressed through collective representation, though one feature of call centre development is its greenfield site location and the associated difficulties facing trade unions in terms of organisation and representation (Dean \& Rainnie 2002; van den Broek 2002). Unions face problems in organising in remote, non-metropolitan locations where shifts are continuous and many workers are on parttime, casual or temporary contracts. This has given rise to discussion of organising strategies and the need for collective employment conditions for workers in the sector. To this end, the ACTU has been successful in negotiating an award for call centre workers in some of the larger call centres (ACTU 2003a). Other strands of research have highlighted management strategies and resistance to trade unions (Todd et al. 2003). At the personal level, there are studies of how workers cope with the pressure and the repetitive work (van den Broek 2002; Healy \& Bramble 2003), with some research on the adaptive anc 
coping strategies of middle managers who often face irreconcilable pressures to reduce costs, maintain staff morale, maintain a routinised yet customised service delivery, and sustain customer service quality (Houlihan 2001). There are studies of subtle and not so subtle forms of active resistance to management and to the extensive controls over and surveillance of work (Bain \& Taylor 2000). Resistance and coping issues are covered by the contributions by Bames and Townsend in this volume.

A third strand of research addresses managerial strategies in call centres in terms of controlling the labour process, developing employment commitment, reducing labour turnover, maintaining service quality, managing stress and burnout, training staff, and integrating ICT into job design. Anecdotal evidence for Australia indicates that call centre work is stressful and associated with tumover rates of around 30 percent (ACTU 2000). Here there is an extensive literature on organising new service work, especially where it is customer focused and involves important 'soft' skills - especially those associated with the application of emotional labour (Mulholland 2002). Strategic HR responses include games, teamwork, the use of bonus and reward recognition systems, the application of performance criteria, and ongoing work appraisal (Hutchinson, Purcell \& Kinnie 2001; Houlihan 2001; Rose 2002). Sophisticated strategies have been designed and implemented that, on the one hand, attempt to enhance commitment and organisational identification, and maintain the quality of service delivery (and competitive position), yet at the same time maintain control (Kinnie, Hutchinson \& Purcell 2001). In this context the systematic HR practices avoid the excesses of the extreme forms of Taylorism (Fernie \& Metcalfe 1998) and attempt to address underlying motivational and commitment problems. The paper by As-Saber, Teicher and Holland in this volume examines HR issues associated with the shift of call centres to off-shore locations.

Another strand of research has addressed the nature and quality of call centre jobs and their potential to deliver jobs and career opportunities to regional locations. The call centre industry is very mobile and transient with respect to location and, as long as the technological infrastructure requirements are fulfilled and there is an available source of trainable and adaptive labour, call centres offer hope to many regions that have in the past found that service sector career jobs are almost the exclusive domain of capital cities (Richardson \& Belt 2001). As such, call centres offer the opportunity for the revival of ailing regional economies, especially those that have suffered from the decline of manufacturing industries. It still remains problematic whether call centre jobs can be filled by the unemployed given that soft skills and customer orientated worker experience is a general pre-requisite for job entry into the sector (Belt 2003). Research by Skene (2003) however, suggests that call centres can be an important employment source for older workers. Several studies have looked at the impact of call centres on regional development, their potential to deliver service jobs, their potential to deliver new economy jobs, and their potential to deliver career service jobs for wómen workers (Belt 2001; Durbin 2003; Richardson, Belt \& Marshall 2000). In both Australia and the UK, the regional location of call centres has been supported by extensive inducements by all tiers of government 
(ACTU 2000; Burgess, Connell \& Drinkwater 2002). Paulet considers locational issues in her contribution in this volume.

Call centres as conveyors of the new economy and new jobs is another strand of research. Its dependence on ICT, its continuous operation, and the linking of call centres across countries brings together many of the characteristics of the new economy (Belt 2003). The customer focus, the networking of call centres and the emphasis on soft skills (especially emotional labour) highlight the modemity aspect of call centres. In addition, call centres can be clustered, offering the possibility for shared in frastructure and the pooling of skilled labour (Richardson \& Belt 2001). Can the jobs be said to be genuinely new economy jobs (Castells 2000)? Is the work highly skilled and requiring extensive training, or is it generally low skill and routinised (getting back to Taylorist discussions)? Richardson and Belt (2001) found that career development in regional call centres was limited, largely because call centres had a flat organisational structure. Durbin (2003) found elements of high skill and extensive training required for some jobs, while for others the work was routinised and required some in-house training. Career development possibilities were dependent on the size of the call centre and its horizontal and vertical links, that is whether it was part of a group of call centres across different locations and whether it was part of a larger business operation (for example, a bank). In this volume Hunt looks at career development possibilities, especially for women workers, in Neu Zealand call centres.

Call centres are becoming globalised operations and call centre jobs are being founc outside of the wealthy OECD economies. The re-location of call centres to countries witl large pools of skilled and relative ly cheap labour is becoming more apparent, especially a: call centres are re-located from Europe, North America, and Australia to India, th Philippines, and South Africa (Burgess, Connell \& Drinkwater 2002; Rose 2002). Cal centres that received public subsidies to establish in regional locations are now in receip of subsidies to relocate to another country. Again, the pressure of cost cutting and th portability of the technology reduce location as a limiting factor. The establishment 0 specialist call centre operations across the globe, combined with the ongoing trend $t$. contract out service provision, facilitates the globalising tendencies of call centre (Burgess, Connell \& Drinkwater 2002). However, the scope for all call centres relocatin outside of advanced economies is neither complete nor straightforward. There are limi1 to complete globalisation including the availability and reliability of ITC infrastructurı the barriers of language and culture, the training and skills of operatives, the managemet problems associated with operating across time zones, and the resistance of customers 1 service operators located outside of their country. The emerging issues associated wit globalisation, especially the growth and development of call centre operations in Indi are discussed by Taylor and Bain; As-Saber, Holland and Teicher; and van den Broek this volume.

An enduring characteristic of call centre research is the heavy reliance on ca: study research methods. While this is understandable in terms of assessing ar 
understanding the labour process, the subtlety, the individual response and adaptation, forms of resistance and coping, the interaction between workers and technology, cultures and relationships, and the details of work and work organisations, it can be problematic in terms of generating an idealised picture of call centres that seems to suggest homogeneity in their operations. Case studies can generate the detailed qualitative information that cannot be captured in surveys; however, the case study is limited by its specificity. The danger is that given the reliance on case study research the research agenda can be potentially distorted by what was found at one or two call centres out of the thousands of operational call centres. In this context Russell's contribution in this volume is important as it highlights the diversity and complexity of call centres.

\section{Overview of the papers in this volume}

The articles in this volume fall into two broad categories - location and labour process. As Taylor and Bain point out in the second paper in this volume, 'Call Centre Offshoring to India: The Revenge of History?', geography and location were of great interest to early researchers of the call centre phenomenon as the emergence of this new and distinctive organisational form promised 'a spatial fix' (Harvey 1982; 2000 cited in Taylor \& Bain's paper, this volume) to problems in capitalism's customer servicing function. From 2000 onwards, the media increasingly reported that US, UK, and Australian companies were locating call centres in India. The prospect of the call centre becoming a genuinely globalised phenomenon, located in the developing world and serving a company's customer base in the developed world, no longer seemed remote.

\section{Location papers}

Phil Taylor and Peter Bain are pioneers of call centre research, especially on the labour process associated with call centre work. As such, we are fortunate to include their analysis of the offshoring of UK call centres to India. They critically and systematically review the assumptions and conditions on which re-location is based. They find that the apparent advantages of lower labour costs have to be placed alongside potential problems and costs associated with the training of operatives, infrastructure problems, and customer resistance to operatives. As the first academic study of the dynamics of call centre offshoring to India, this paper breaks new ground, presenting evidence from a two-year research project. Firstly, the authors analyse current outsourcing practices, and interrogate the future intentions of call centre firms operating in Scotland. As a key region of call centre activity, Scotland provides a useful prism through which general trends can be evaluated. Secondly, the authors provide a comprehensive review of developments in the Indian sector. Synthesising research findings from Scotland and India enables the identification and analysis of factors driving, facilitating and inhibiting call centre migration. 
The third paper in this volume, 'Call Centres in India: An Eclectic Phenomenon in Global Human Resource Management' by Sharif As-Saber, Peter Holland and Julian Teicher, examines the paradoxes and problems of managing human resources in a global context. This paper culminates in the development of a framework to assist in the research of human resources from a global, multi-disciplinary context. The authors point out that India hosts the largest number of call centres that are working for, or are offshoots of, Western companies such as HSBC, BT, GE Capital and British Airways, with every call centre tailored to serve the purpose of the individual client company. Thus, the management style together with the control mechanisms and the various human resources management (HRM) issues tend to vary from one company to another. Nonetheless, there are some common HR issues that impact on call centre management in India (for example, customer management across time zones), with the interplay of the various convergences and divergences providing an interesting perspective of call centre HR management that is explored in this paper.

The fourth paper in this volume, by Diane van den Broek - 'Globalising Call Centre Capital: Gender, Culture and Work Identity' - focuses, as the title suggests, on how various work cultures interrelate with the process of globalisation. van den Broek posits that, as in other industries, the global restructuring of call centre capital to countries like India is not an abstract process based on undifferentiated labour power but has quite specific socio-cultural implications. Given the naturè of the call centre labour process, emotional and aesthetic labour are identified as important influences on what waged work means and how workers see themselves within wider social relations. An optimistic analysis of call centre re-location to India would suggest that corporations bring with them employment opportunities, technical infrastructure, and human resource developments such as training. A more pessimistic interpretation suggests that we are witnessing an ever-deepening exploitation on an international scale as foreign-owned firms reel in the profit at the expense of cheap labour, a sort of 'black hole of Calcutta' analysis. While these interpretations are not mutually exclusive, van den Broek's analysis focuses on the wider socio-cultural implications of these developments on India's call centre workforce.

The next paper, by Renee Paulet, examines location, and HR policy and practice in call centres. The paper, entitled 'Putting Call Centres in their Place', considers the importance of location in call centre research. Important questions that emerge include the impact of place on location decisions, on the nature of work performed, and the way call centre employees are managed. The paper considers if, and how, place impacts on the HR policies and practices within call centres.

\section{Labour Process papers}

The next group of papers in this volume loosely focuses on the labour processes within call centres. This includes the nature of call cantre jobs, issues of control and worker 
resistance, and the gendered division of labour within call centres. The outsourcing of labour has been seen as symptomatic of the erosion of internal labour markets and a sign of the increased importance of market-based activities and relatively short-term contractual arrangements (Jacoby 1999). Deery and Walsh (2002) point out that it has been suggested that the wider use of outsourcing and subcontracting has led to the employment relationship becoming mediated by the market rather than insulated from the market. Consequently, a different type of employment contract has emerged whereby work arrangements have involved the substitution of arms-length market-mediated transactions for direct employment relationships (Abraham 1990). As a result, the growth in outsourcing and subcontracting has been said to foreshadow the 'revival of contract as the foremost organizing mechanism of economic activity' (Deakin \& Michie 1997).

In his paper, 'Are All Call Centres the Same?', Bob Russell provides an assessment of Foucaldian, labour process and neo-Weberian approaches to call centre employment through a comparative case study analysis. A detailed examination of four Australian call centres suggests a convergence of conditions not only around common technologies but also with respect to shared cultural artifacts. Where differentiation was found, it was related to the history, or lack there of (that is, brownfield versus greenfield site location), of the operation, as opposed to employer choice of instrumental or high commitment employment systems. Russell concludes that it is necessary to qualify labour process theory in relation to the study of call centres, as the work of the call centre operatives is considerably different from the conditions faced by the industrial subjects that have formed the mainstay of labour process accounts thus far. This paper represents one of the most extensive theoretical reviews of call centre labour process and one of the most extensive overviews of call centre research in Australia.

Keith Townsend's paper, 'When The LOST Found Teams: A Consideration of Teams with in the Individualised Call Centre Environment', explores what he refers to as the team paradox within a case study organisation. His research demonstrates that employees within the same teams may take a very different approach to team importance within the highly individualised workplace of the call centre. In this case study, one team in particular complicates management policies by 'turning the tables' on management and using their team cohesiveness to challenge managerial prerogative. Hence, this case study provides many examples of employees spending time and energy finding ways to manipulate the system to engage in activities of resistance. Not all these activities have a negative effect on the organisation. Townsend suggests that a cynical consideration of developments throughout industrialised history, along with a moderate respect of science fiction entertainment, results in a failure to completely exclude the notion of chimerical control from playing a role in workplaces of the future. Evidence from this case study suggests that employees are continuing the cycle of control and resistance uncovered throughout industrialised history.

'Diaries, Dunnies and Discipline: Resistance and Accommodation to Monitoring in Call Centres', by Alison Barnes, explores the interplay of resistance and accommodation. 
Barnes examines three call centres and her findings suggest that, although the technology in use has potentially augmented management's control over the labour process, this development has not gone unchallenged. In her study she found that employees set up ways to manipulate the technology and exploit its weaknesses, thereby gaining a measure of control over what was often seen as unfair managerial practice. Employee responses to technology were complex and contradictory. Some welcomed performance monitoring, not out of unquestioning acquiescence, but in an attempt to control the use of performance statistics and the activities that were monitored. Employees utilised accommodation and resistance both separately and concurrently as circumstances dictated. Barnes suggests that an explanation of these seemingly contradictory responses may lie in notions of self worth and self-preservation.

The final paper in this volume explores the notion of call centre work as a career for women. 'Call Centre Work for Women: Career or Stopgap?' by Vivienne Hunt points out that the majority of literature characterises call centres as workplaces beset by high levels of stress, worker burnout, limited career paths, and high staff turnover. The position of women is also portrayed negatively in much of the extant call centre literature, with many researchers finding women still face a number of barriers that prevent their promotion to management within a predominantly female workforce. Hunt's paper contests the claim that there are limited career trajectories for women in call centres with her exploratory research suggesting that the call centre work experience provides product or company knowledge and skills which may assist women in gaining promotion to management positions, internally or extemally. As Hunt points out though, the New Zealand call centre industry is dominated by small and government sector call centres, which may explain why her research findings on women and call centre work in New Zealand may be different to those found in the call centre international literature.

\section{Conclusions}

Call centres have been part of the internal restructuring of business operations, the segmentation of service delivery, and the extended division of labour within an organisation. This restructuring process is clearly facilitated by IT developments that allow for the intensive division of labour and the external re-location of call centre functions

It was recently reported in the British media that trade unions are lobbying the government to prevent the loss of call centre jobs to offshore locations, as large Britist corporations, such as British Telecom (BT), establish outsourced call centre operations ir ICT agglomerations in Bangalore and Delhi, India. The BT Retail Chief Executive said tha BT's two call centres in India, which will employ 2,200 workers by the end of 2003 wert proving to be a great success, and were up to 40 percent cheaper than those in the UK The Communication Workers Union claimed that strategies, such as BT's, will put ove 200,000 call centre and service sector jobs at risk over the next five years (Ananova 2003) In terms of industry evolution and development, it seems that call centres are moving inte a phase of outsourcing and internationalisation. Both offer cost and strategic opportunitie 
and both are viable through ICT developments.

Pressures on organisations to remain competitive are encouraging many more to relocate jobs in the technology industries and call centres to offshore locations such as India. Where developing nations have grown their skill base to compete with Western nations, considerable cost advantages can be accrued - as has occurred for some time in the textile industry. Recently IBM (who contract to Telstra) indicated that they will relocate software development offshore to India. It is estimated that this will cost 450 local jobs, leading the current Treasurer to ask Telstra to provide a very good reason as to why these employment opportunities cannot be provided in Australia (The Age 2004).

So it seems that while call centre jobs have increased at a rapid rate worldwide, they may be under threat in countries where labour costs are higher than those currently found in offshore locations, though as contributions to this volume indicate, there are limits to offshoring call centre operations. While examination of the labour process of call centres dominated the earlier discourse on call centre operations, capturing the intersection between the new economy and old management systems, the evolution of call centres means greater uncertainty for both managers and employees. While this generates more pressure to perform, it will also mean that no matter how effectively a call centre is organised and how efficient its operations are, it can always be replaced with something more efficient or with something that is cheaper to operate. However, there are limits to a relocation strategy based solely on cost savings. Some relocations have been reversed as a result of customer resistance to and dissatisfaction with the quality of the offshore service (ACTU 2003b).

While there is a growing body of research on call centre management in the UK and the USA, empirical studies in Australia still appear to be at an embryonic stage (Crone, Carey \& Dowling 2001). This volume is timely in that it outlines the emerging trends of calt centre research in Australia. It also brings together some of the established pioneers of call centre labour process research in Australia (Bob Russell \& Diane van den Broek), with the ongoing research by post graduate students (Alison Barnes, Keith Townsend, Renee Paulet \& Vivienne Hunt). The keynote contribution by Phil Taylor and Peter Bain, together with the examination of the Indian call centre industry by Shaif As-Saber, Peter Holland and Julian Teicher, highlights the ongoing global development of the industry. 


\section{Acknowledgements}

We thank those who participated in the call centre research conference at the University of Newcastle, December 2003. The conference received financial support from the University of Newcastle Research Grants Committee. Selected papers from the conference form the content of this special issue of Labour \& Industry. We thank the referees of the articles and the editors of Labour \& Industry for their support and we acknowledge the hard work of Kate Flint in organising the correspondence and undertaking the editing and formatting that was necessary to produce this special issue.

\section{References}

Abraham, KG (1990) 'Restructuring the employment relationship: The growth of market-mediated work arrangements' in KG Abraham \& RB McKersie (eds.), New Developments in the Labor Market: Toward A New Institutional Paradigm, MIT Press: Cambridge, MA, pp. 85-119.

Ananova (2003) 'India call centres better, claims BT chief http://www.ananova.com/news/story/ sm 800526.html?menu (accessed November 2003).

Anonymous (2002) Companies Invest In IT To Improve Call Center Agent Performance - New Report, Contact Center World.

Australian Coucil of Trade Unions [ACTU] (2000) 'On Line: the Future of Australia's Call Centre Industry' www.actu.asnau/public/papers/ontheline

Australian Council of Trade Unions [ACTU] (2003a) 'Call Centre Workers Win \$1000 Windfall' www.actu.asn/public/campaignes/callcentral/award (accessed 28 October 2003).

Australian Council of Trade Unions [ACTU] (2003b) 'Myer Diverts Jobs Back From Delhi' www.actu.asn/public/campaignes/callcentral/back from Delhi. (accessed 28 October 2003)

Bain, P \& Taylor, P (2000) 'Entrapped by the Electronic Panopticon? Workers Resistance in Call Centres' New Technology, Work and Employment. 15(1) pp. 2-17.

Belt, V (2001) 'A Female Ghetto? Women's Careers in Call Centres' Conference on Call Centres and Beyond: the HRM.Implications. Kings College, London, November.

Belt, V (2003) 'Work, Employment and Skill in the New Economy: Training for Call Centre Work in North East England' 21" Annual Labour Process Conference, Bristol, April.

Burgess, J, Connell, J \& Drinkwater, J (2002) 'Regional Call Centres: New Economy, New Work and New Work Organisations' Conference on the New Regionalism in Australia. Monash, Gippsland, November.

Castells, M (2000) The Information Age: Economy, Society and Culture: Vol. I. Blackwell: Oxford Crone, G, Carey, L\& Dowling, PJ (2001) 'Compensation Strategies in Telephone Call Centres: An Australian Perspective' The Human Resource Management Journal Special Edition, King's College, London, pp. 1-39. 
Deakin, S \& Michie, J (1997) Internal Labour Markets and Manpower Analysis DC Heath: Lexington, M.A.

Dean, A \& Rainnie, A (2002) 'Symbolic Analysts in the New Economy? Call Centres in Less Favoured Regions' Conference on New Regionalism in Australia, Monash University, Gippsland, November.

Deery, S \& Kinnie, N (2002) 'Call Centres and Beyond: A Thematic Evaluation' Human Resources Management Journal 12(2) pp. 3-13.

Deery, S \& Walsh, J (2002) Contracting out and market-mediated employment arrangements: outsourcing call centre work - the Management Centre Research Papers, RP 010, Kings College, London.

Durbin, S (2003) 'Call Centres in the Financial Services Sector: New Opportunities for Women in

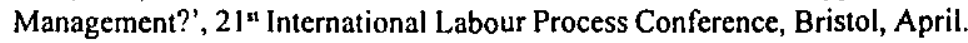

Fernie, S \& Metcalfe, D (1998) 'Not Hanging on the Telephone: Payment Systems in the New Sweatshops' Discussion Paper No. 390, Centre for Economic Performance, London School of Economics.

Healy, J \& Bramble, T (2003) 'Dial 'B' for Burnout? The Experience of Job Bumout in a Telephone Call Centre', Labour \& Industry 14(2) pp. 39-59.

Houlihan, M (2001) 'Managing to Manage? Stories from the Call Centre Floor' Journal of European Industrial Training 25(2) pp. 208-23.

Hutchinson, S, Purcell, J \& Kinnie, N (2001) 'Evolving High Commitment Management and the Experience of the RAC Call Centre' Human Resources Management Journal 10(1) pp. 6378.

Incomes Data Services [IDS] (2001) Pay and Conditions in Call Centres, Incomes Data Services: London.

Jacoby, S (1999) 'Are career jobs headed for extinction?' California Management Review, 42(1) Fall, pp. 123-45.

Kinnie, N, Hutchinson, S \& Purcell, J (2001) 'Fun and Surveillance: the Paradox of High Commitment Management in Call Centres' International Journal of Human Resources Management 1 (5) pp. 967-85.

Mulholland, K (2002) 'Gender, Emotional Labour and Teamworking in a Call Centre' Personnel Review 31(3) pp. 283-303.

Richardson, R \& Belt, V (2001) 'Saved by the Bell? Call Centres and Economic Development in Less Favoured Regions' Economic and Industrial Democracy 22, pp. 67-98.

Richardson, R, Belt, V \& Marshall, N (2000) 'Taking Calls to Newcastle: the Regional Implications of Growth in Call Centres' Regional Studies 34(4) pp. 357-76.

Rose, E (2002) 'The labour process and Union commitment within a banking services call centre' Journal of Industrial Relations 44(1) pp. 40-61.

Russell, B (2002) 'The Talk Shop and Shop Talk: Employment and Work in a Call Centre' Journal of Industrial Relations 44(4) pp. 467-90.

Skene, J (2003) 'Teaching Old Dogs New Tricks: Accessing Employment Opportunities for Mature Workers in the Call Centre Industry', AIRAANZ Conference, Monash University, Melbourne. 
Taylor, P \& Bain, P (1999) 'An Assembly Line in the Head: Work and Employee Relations in the Call Centre' Industrial Relations Journal 30, pp. 101-17.

Taylor, P, Hyman, J, Mulvey, G \& Bain, P (2002) 'Work organization, control and the experience of work in call centres' Work, Employment and Society 16(1) pp. 133-50

The Age (2004) 'Costello says Telstra should keep IT jobs in Australia' http:/www.theage.com.au/ articles/2004/01/14/1073877871775.html (accessed January 2004).

Todd, P, Eveline, J, Still, L \& Skene, J (2003) 'Management responses to Unions in Australian call centres: Exclude, tolerate or embrace?' AIRAANZ Conference, Monash University, Melbourne.

van den Broek, D (2002) 'Monitoring and Surveillance in Call Centres: Some Responses from Australian Workers' Labour \& Industry 12(3) pp. 43-58.

JOHN BURGESS \& JULIA CONNELL - Employment Studies Centre, University of Newcastle 